\title{
Water Productivity for Egyptian Clover as Affected by Different Irrigation Regimes and Cultivation Methods in The North Middle Nile Delta Region
}

\author{
R. Kh. Darwesh \\ Soils, Water \& Environment, Res. Inst.(SWERI), A.R.C., Egypt.
}

\begin{abstract}
A FIELD experiment was conducted in the two successive winter seasons ( 2016-17 and 2017-18) to investigate the impact of cultivation method; dry cultivation ( dry seed on dry soil) and traditional one (wet seed on wet soil) and irrigation regime; five different irrigation regimes as follows, irrigation till $5 \mathrm{~cm}$ above soil surface, (traditional, $\mathrm{I}_{1}$ ), using soil moisture depletion $\left(\mathrm{I}_{2}\right)$, irrigation with 0.8 from pan evaporation $\left(\mathrm{I}_{3}\right)$, irrigation with Hargreaves equation, $1981\left(\mathrm{I}_{4}\right)$ and irrigation till $2.5 \mathrm{~cm}$ above soil surface $\left(\mathrm{I}_{5}\right)$.

The obtained results showed that decreasing amount of irrigation water from traditional method $\left(\mathrm{I}_{1}\right)$ to $2.5 \mathrm{~cm}$ above soil surface $\left(\mathrm{I}_{5}\right)$ reduced fresh yield by 5.49 and 6.75 ton fed.$^{-1}$ with water saving $\approx 14.5 \%\left(\approx 336.0 \mathrm{~m}^{3} \mathrm{fed} \cdot{ }^{-1}\right.$,) for dry seeds cultivation method, and the corresponding values 4.87 and 7.34 ton fed. ${ }^{-1}$ with water saving $10.75 \%\left(\approx 280.0 \mathrm{~m}^{3}\right.$ fed. $\left.{ }^{-1},\right)$ for wet cultivation one in the overall seasons. Meaningfully, an average of $\approx 700-840$ million $\mathrm{m}^{3}$ water could be saved at the national level $(\approx 2.5$ million fed.). Moreover, mean reduction in dry yield by $24.62 \mathrm{~kg}$ fed. ${ }^{-1},(6.35 \%)$ and $13.00 \mathrm{~kg} \mathrm{fed}^{-1}(3.51 \%)$ could be resulted from dry cultivation method, and by $36.45 \mathrm{~kg} \mathrm{fed}^{-1}(8.68 \%)$ and $10.91 \mathrm{~kg} \mathrm{fed}^{-1}(2.60 \%)$ could be resulted from wet cultivation method in the first and second seasons respectively.

The highest overall mean values of water consumptive use (CU) and consumptive use efficiency (Ecu, \%) were recorded irrigation without any stress during the growing season $\left(\mathrm{I}_{1}\right)$. Productivity of irrigation water $\left(\mathrm{PIW} \mathrm{kgm}{ }^{-3}\right.$ ) and water productivity $\left(\mathrm{WP} \mathrm{kgm}^{-3}\right)$ for fresh yield was the highest values recorded under $I_{5}$ (the lowest water consumed) for dry and wet cultivation methods.
\end{abstract}

Keywords: Irrigation regime, Cultivation methods, Crop water productivity; Egyptian clover crop.

\section{Introduction}

Water is one of the most fundamental important inputs for the production of crops. Maximizing productivity of irrigation water by crops is the main issue in the agriculture sector to increase crop production in order to narrow the food gap. Water affects the achievement of crops not only directly but also indirectly by influencing the availability of nutrients, the timing of cultural operating....etc. The Egyptian water share from the main water source, River Nile, is limited by $55.5 \times 10^{9} \mathrm{~m}^{3}$ year-1, which is not enough to meet the water demands of all sectors. About $80-85 \%$ of the national water equipping is used in agricultural sector. Rationalize the use of irrigation water through maximizing productivity of irrigation water by crops becomes a must. Geerts and Raes (2009) investigate the concept of water productivity to be an important issue and warned that due to the current development policy adopted in the world, the pressure on water resources for food production will increase, and water consumption will reach $5.600 \mathrm{~km}^{3}$ year ${ }^{1}$ in 2050 , represents three times the amount of water currently used for irrigation worldwide. Crop-water requirements vary during the growing period, mainly due to variation in crop canopy and climatic conditions, and are governed by crop evapotranspiration (ET). Thus, an accurate

*Corresponding author e-mail: r darwesh82@yahoo.com 
estimation of crop ET is a very important factor for efficient water management (Tyagi et al., 2000).

Egyptian clover (Trifoliumalexandrinum L.) considers one of the most important leguminous forages in the Mediterranean region and Middle East, with a fast growth rate, high quality forage and very low bloating potential. Growing these legumes with grass improves the nutritive value and qualitative characteristics of the forage mixture compared with grass alone (Zemenchik et al., 2002).

A fast-growing summer annual, Egyptian clover can produce high forage under irrigation. It's a heavy Nitrogen $(\mathrm{N})$ producer and the least winter hardy of all true annual clovers. This makes it an ideal winter cover before all summer crops nitrogen-demanding crops. Berseem clover draws down soil $\mathrm{N}$ early in its cycle.

Irrigation water management could be achieved via a grate determination of the amount and timing of applied irrigation water in a planned and efficient manner. With good irrigation management, a Berseem hay crop can have high yield and quality potential. Berseem is a high water use forage crop because it generates a substantial amount of above ground biomass, and has a longer growing season comparing with other irrigated crops.

Water productivity points are also useful for looking at the potential increase in crop yield that may result from increased water availability (Singh et al., 2006). Nyati (1996) suggested that the greatest benefit from limited water can be obtained from early application prior to all canopy cover. They provide a proper vision of where and when water could be saved.

Under water deficiency conditions, reduction of the cultivated area yielded higher water productivity values as compared to deficit irrigation (Vazifedoust 2008 )

Abbas et al. (1995) studied the impact of the planting method and the irrigation management (one, two and three irrigations between cuttings) on fresh and dry yield of berseem. The results revealed that the optimum yield was obtained from the two methods of planting, i.e. the ElLamaa method and the dry method with three irrigation between cuttings. In addition, El-Bably (2002) revealed that three irrigation between cuttings significantly increased fresh and dry yields, however, it decreased water use efficiency, indicated also water consumed values were 59.62, 48.98 and $37.98 \mathrm{~cm}$, over both seasons, for three, two and one irrigation between cuttings treatments, respectively. Moreover, Kassab (2006) stated that dry cultivation is an effective method for irrigating Egyptian clover in North Nile Delta region as a result of saving an amount of irrigation water.

Kassab et al., (2012) found that average values were $32.81,34.01$ and 34.62 ton fed $^{-1}$ for dry, semi-dry and the common cultivation, respectively, and higher values of yield per unit applied water (WUtE) as well as consumed water (WUE) averaging $15.52,15.68 \mathrm{~kg} / \mathrm{m}^{3}$ and 20.06 , $19.74 \mathrm{~kg} / \mathrm{m}^{3}$ for dry and semi-dry cultivation, respectively comparing with $15.07 \mathrm{~kg} / \mathrm{m}^{3}$ applied and $18.47 \mathrm{~kg} / \mathrm{m}^{3}$ consumed, respectively under the wet cultivation method. Din SI et al., (2014) found that the seed yield for Egyptian clover was severely reduced about $47 \%$ when the irrigation was decreased from ten to four waterings; this could be, because of flowers and head abscission under moisture stress. Shah Jahan Leghari et al., (2018) studied that irrigation with 15 days interval, 8 irrigations with 18 days interval and 4 irrigations with 21 days interval and found that 12 irrigations with 15 days interval produced significant green fodder and seed yield.

The main objectives for this current investigation are to determine the effect of different cultivation methods and the studied irrigation water regime on improving irrigation performance and optimizing water productivity, yield, some yield attributes and some water relations.

\section{Materials and Methods}

A field experiment was conducted at Sakha Agricultural Research Station The site lies at Kafr EL Sheikh Governorate, the North Middle of the Nile Delta region, during the two growing seasons $2016 / 17$ and $2017 / 18$. The aim of this study was to find out the impact of cultivation method and irrigation regime on yield and some water relationships of Egyptian clover (Berseem) crop.

Soil samples and irrigation water were taken and analyzed at Soil, Water and Environment Research Institute (SWERI) Lab, Agricultural Research Center (ARC).

Soil samples were taken from the experimental site at four depths; 0-15, 15-30, 30-45 and 45-60 $\mathrm{cm}$, and prepared, to determine some physical 
and chemical characteristics of the soil before cultivation. According to Black (1965) and Jakson (1967), respectively. Where, $\mathrm{SO}_{4}$ was calculated by the difference between soluble cations and anions.

Irrigation and drainage water was also analyzed and the obtained data are presented in Table 2

While, the climatological parameters during the studied period, were obtained from Sakha Agrometeorological Station. The parameters, include; air temperature $\left(\mathrm{T} ., \mathrm{C}^{\circ}\right)$, relative humidity $(\mathrm{RH} ., \%)$, wind speed $\left(\mathrm{U}_{2}, \mathrm{~km} /\right.$ day at $2 \mathrm{~m}$ height $)$ and evaporation pan (Ep, $\mathrm{mm}$ ). as tabulated in Table 3

\section{Experimental design and treatments:}

A field trial was conducted during the above mentioned seasons. The experimental design for this present work was a factorial; split plot design with three replications, involving two factors i.e. cultivation methods and irrigation regime. Main plots were assigned to the cultivation methods as follows:

A. Dry cultivation method (Dry seeds broadcasting over dry soil).

B.Wet cultivation (presoaked seeds broadcasting over wet soil or traditional).

The subplots were assigned to the irrigation regime as follows:

TABLE 1. Soil physical and chemical properties as well soil-water constants:

\begin{tabular}{|c|c|c|c|c|c|c|c|c|}
\hline \multicolumn{9}{|c|}{ Soil physical characteristics } \\
\hline \multirow{2}{*}{$\begin{array}{r}\text { Soil } \\
\text { depth } \\
\text { Cm }\end{array}$} & \multicolumn{3}{|c|}{ Particle size distribution } & \multirow[b]{2}{*}{ Texture class } & \multirow{2}{*}{$\begin{array}{c}\text { Bulk } \\
\text { Density, } \\
{\mathrm{Mg} / \mathbf{m}^{3}}^{3}\end{array}$} & \multirow{2}{*}{$\begin{array}{l}\text { F.C. } \\
\%{ }^{*}\end{array}$} & \multirow[b]{2}{*}{ P.W.P \% \%* } & \multirow{2}{*}{$\begin{array}{l}\text { Available } \\
\text { water \% }\end{array}$} \\
\hline & Sand\% & Silt\% & Clay \% & & & & & \\
\hline $0-15$ & 11.60 & 33.80 & 54.60 & Clayey & 1.04 & 43.53 & 23.66 & 19.87 \\
\hline $15-30$ & 19.30 & 34.40 & 46.30 & Clayey & 1.05 & 38.41 & 20.88 & 17.53 \\
\hline $30-45$ & 21.10 & 40.70 & 38.20 & Clay loam & 1.09 & 36.06 & 19.60 & 16.46 \\
\hline $45-60$ & 21.10 & 40.65 & 38.25 & Clay loam & 1.14 & 34.65 & 18.83 & 15.82 \\
\hline Mean & 18.30 & 37.38 & 44.32 & Clay loam & 1.08 & 38.16 & 20.74 & 17.42 \\
\hline
\end{tabular}

Chemical characteristics

\begin{tabular}{|c|c|c|c|c|c|c|c|c|c|c|}
\hline \multirow[b]{2}{*}{$\begin{array}{l}\text { Soil } \\
\text { depth } \\
\text { cm }\end{array}$} & \multirow[b]{2}{*}{$\begin{array}{c}\mathrm{pH} \\
1: 2.5 \\
\text { S.w.S*** }\end{array}$} & \multirow[b]{2}{*}{$\begin{array}{c}E C \\
\text { ds } m^{-1}\end{array}$} & \multicolumn{5}{|c|}{ Soluble cations, meq/l } & \multicolumn{3}{|c|}{ Soluble anions meq/l } \\
\hline & & & $\mathrm{Ca}^{++}$ & $\mathrm{Mg}^{++}$ & $\mathrm{Na}^{+}$ & $\mathbf{K}^{+}$ & $\mathrm{CO}_{3}=$ & $\mathrm{HCO}_{3}^{-}$ & $\mathrm{Cl}^{-}$ & $\mathrm{SO}_{4}=$ \\
\hline $0-15$ & 8.45 & 2.85 & 4.85 & 3.99 & 19.38 & 0.29 & - & 4.40 & 16.15 & 7.96 \\
\hline $15-30$ & 8.36 & 3.42 & 5.81 & 4.79 & 23.26 & 0.34 & - & 4.10 & 16.05 & 14.05 \\
\hline $3045-$ & 8.37 & 3.54 & 6.02 & 4.96 & 24.07 & 0.35 & - & 4.10 & 12.09 & 19.31 \\
\hline $45-60$ & 8.35 & 3.99 & 6.78 & 5.59 & 27.13 & 0.40 & - & 4.00 & 16.10 & 19.80 \\
\hline Mean & --- & 3.45 & 5.87 & 4.83 & 23.46 & 0.35 & - & 4.15 & 15.10 & 15.26 \\
\hline
\end{tabular}

*F.C.: Field capacity, **P.W.P. Permanent wilting point and *** S.w.S soil water suspension

TABLE 2. Chemical properties of irrigation and drainage water:

\begin{tabular}{|c|c|c|c|c|c|c|c|c|c|c|}
\hline \multirow[b]{2}{*}{$\begin{array}{c}\text { Water } \\
\text { type }\end{array}$} & \multirow[b]{2}{*}{ SAR } & \multirow[b]{2}{*}{$\begin{array}{l}\text { E.C } \\
\text { ds } / \mathrm{m}\end{array}$} & \multicolumn{4}{|c|}{ Soluble cations meq/l } & \multicolumn{4}{|c|}{ Soluble anions meq/l } \\
\hline & & & $\mathrm{Ca}^{++}$ & $\mathrm{Mg}^{++}$ & $\mathrm{Na}^{+}$ & $\mathbf{K}^{+}$ & $\mathrm{CO}_{3}^{-}$ & $\mathrm{HCO}_{3}=$ & $\mathrm{Cl}^{-}$ & $\mathrm{SO}_{4}=$ \\
\hline IW* $^{*}$ & 5.73 & 0.64 & 1.09 & 0.90 & 4.35 & 0.06 & 0.00 & 2.5 & 3.05 & 0.85 \\
\hline $\mathrm{D}^{* *}$ & 8.30 & 1.34 & 2.28 & 1.88 & 9.11 & 0.13 & 0.00 & 5.5 & 6.38 & 1.52 \\
\hline
\end{tabular}

*IW: Irrigation water ** D: Drainage water 
TABLE 3. Some meteorological parameters during the two growing seasons of Berseem 2016-2017 and 2017-2018.

\begin{tabular}{|c|c|c|c|c|c|c|c|c|c|c|}
\hline & \multirow{2}{*}{ Months } & \multicolumn{3}{|c|}{$\mathbf{T}\left(\mathbf{c}^{\circ}\right)$} & \multicolumn{3}{|c|}{ RH(\%) } & \multirow{2}{*}{$\begin{array}{c}\text { U2 } \\
\text { km d-1 }\end{array}$} & \multirow{2}{*}{$\begin{array}{c}\text { Pan } \\
\text { Evap. }(\mathrm{mm} / \\
\text { day) }\end{array}$} & \multirow{2}{*}{$\begin{array}{c}\text { R.F } \\
\text { mm/ } \\
\text { month }\end{array}$} \\
\hline & & Max. & Min. & Mean & Max. & Min. & Mean & & & \\
\hline \multirow{7}{*}{$\begin{array}{l}\bar{D} \\
\stackrel{0}{0} \\
b \\
\frac{1}{0}\end{array}$} & Oct. & 29.80 & 21.70 & 25.75 & 82.40 & 55.30 & 68.85 & 92.20 & 3.57 & --- \\
\hline & Nov. & 24.93 & 17.93 & 21.43 & 77.87 & 56.79 & 67.42 & 56.00 & 1.98 & --- \\
\hline & Dec. & 19.66 & 10.72 & 15.19 & 85.42 & 65.31 & 75.37 & 64.70 & 1.57 & 25.84 \\
\hline & Jun. & 18.17 & 5.71 & 11.94 & 87.81 & 62.42 & 75.11 & 51.90 & 1.36 & 9.60 \\
\hline & Feb. & 19.61 & 9.79 & 14.70 & 86.00 & 59.93 & 72.96 & 58.30 & 2.15 & 25.20 \\
\hline & March & 22.45 & 17.99 & 20.22 & 84.90 & 60.32 & 72.61 & 83.52 & 2.97 & -- \\
\hline & Apr. & 26.51 & 21.59 & 24.05 & 79.37 & 50.83 & 65.10 & 89.30 & 4.64 & 10.60 \\
\hline \multirow{7}{*}{ 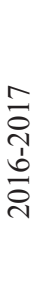 } & Oct. & 28.70 & 24.00 & 26.35 & 81.10 & 54.70 & 67.90 & 73.20 & 3.27 & --- \\
\hline & Nov. & 23.70 & 19.90 & 21.80 & 84.70 & 58.60 & 71.65 & 53.50 & 2.06 & 9.3 \\
\hline & Dec. & 21.30 & 18.40 & 19.85 & 88.20 & 64.80 & 76.50 & 42.90 & 1.47 & 5.60 \\
\hline & Jun. & 18.90 & 13.60 & 16.25 & 89.40 & 64.40 & 76.90 & 44.90 & 2.63 & 36.40 \\
\hline & Feb. & 21.60 & 14.60 & 18.10 & 87.60 & 63.40 & 75.50 & 34.70 & 2.78 & 16.60 \\
\hline & March & 25.40 & 16.60 & 21.00 & 82.30 & 48.30 & 65.30 & 46.40 & 4.22 & --- \\
\hline & Apr. & 27.80 & 20.00 & 23.90 & 80.90 & 43.90 & 62.40 & 74.00 & 5.32 & --- \\
\hline
\end{tabular}

*Source: meteorological station at Sakha $31^{\circ} 07^{-} \mathrm{N}$ Latitude, $30^{\circ} 57^{-}$longitude with an elevation of 6 metres above mean sea level.

1: irrigation till $5.0 \mathrm{~cm}$ above soil surface (traditional), $\mathrm{I}_{1}$

2: irrigation based on soil moisture depletion $(\mathrm{SMD}), \mathrm{I}_{2}$

3: irrigation with 0.8 pan evaporation (Ep), $\mathrm{I}_{3}$

4: Irrigation according to Hargreaves et al., equation (1985), $\mathrm{I}_{4}$

$\mathrm{ET}_{0}=0.0023$ Ra.TD0.5 (Ta +17.8) as:

$\mathrm{ET}_{0}=$ reference evapotranspiration, $\mathrm{mm}$,

$\mathrm{Ra}=$ extraterrestrial radiation

$\mathrm{TD}=$ difference of temperature (Tmax - Tmin)

$\mathrm{Ta}=$ mean temperature.

5: irrigation till $2.5 \mathrm{~cm}$ above soil, $\mathrm{I}_{5}$.

Irrigation water (I.W):

Applied water was controlled and measured by orifice with fixed dimension. The amount of water delivered through the spile tube was calculated according to Majumdar (2002) by the equation;

Where:

$$
\mathrm{q}=\mathrm{CA} \sqrt{ } 2 \mathrm{gh}
$$

$\mathrm{q}=$ Discharge of irrigation water $\left(\mathrm{cm}^{3} / \mathrm{s}\right)$,

$\mathrm{C}=$ Coefficient of discharge $=0.61$ (determined by experiment),

$\mathrm{A}=$ Inner cross section area of the irrigation spile (cm2),

$\mathrm{g}=$ Gravity acceleration $(\mathrm{cm} / \mathrm{s} 2)$ and

$\mathrm{h}=$ Average effective head $(\mathrm{cm})$.

The volume of water delivered for each plot $\left(6 \mathrm{~m} \times 7 \mathrm{~m}=42 \mathrm{~m}^{2}\right)$ was calculated by substituting
$\mathrm{Q}$ in the following equation:

Where:

$$
\mathrm{Q}=\mathrm{q} \times \mathrm{T} \times \mathrm{n}
$$

$\mathrm{Q}=$ volume of water $\mathrm{m}^{3} /$ plot,

$\mathrm{q}=$ discharge $(\mathrm{m} 3 / \mathrm{min})$,

$\mathrm{T}=$ total irrigation time $(\mathrm{min})$ and

$\mathrm{n}=$ number of spiles tube per each plot.

Water consumptive use, $\mathrm{cm}$ :

Water consumptive use was calculated as soil moisture depletion (SMD) according to Hansen et al. (1979).

$$
C u=S M D=\sum_{\mathrm{i}=1}^{\mathrm{i}=\mathrm{N}} \frac{\theta_{2}-\theta_{1}}{100} * D b i * D i
$$

Where:

$\mathrm{CU}=$ Water consumptive use in the effective root zone, $\mathrm{cm}$,

$\Theta_{2}=$ Gravimetric soil moisture percentage 48 hours after irrigation,

$\Theta_{1}=$ Gravimetric soil moisture percentage before irrigation,

Dbi $=$ soil bulk density $\left(\mathrm{Mg} \mathrm{m}^{-3}\right)$ for the given depth,

$\mathrm{D}_{\mathrm{i}}=$ soil layer depth $(20 \mathrm{~cm})$,

$\mathrm{i}=$ number of soil layers each $(15 \mathrm{~cm})$ depth and

Crop- water relations:

Water productivity WP $\mathrm{kg} \mathrm{m}^{-3}$ :

Water productivity is generally defined as crop yield per cubic metre of water consumption. It was calculated according to (Ali et al., 2007) 
Where:

$$
W P=\frac{G Y}{E T}
$$

$\mathrm{WP}=$ water productivity $\left(\mathrm{kg} \mathrm{m}^{-3}\right)$,

$\mathrm{GY}=$ yield $\left(\mathrm{kg} \mathrm{fed}^{-1}\right)$ and

$\mathrm{ET}=$ Total water consumption of the growing season $\left(\mathrm{m}^{3} \mathrm{fed}^{-1}.\right)$.

Productivity of irrigation water PIW $\mathrm{kg} \mathrm{m}^{-3}$ :

Productivity of irrigation water (PIW) was calculated according to (Ali et al., 2007).

Where:

$$
P I W=\frac{G Y}{I W}
$$

$\mathrm{PIW}=$ productivity of irrigation water $\left(\mathrm{kg} \mathrm{m}^{-3}\right)$,

$\mathrm{Gy}=$ yield $\mathrm{kg} /$ fed and

$\mathrm{Wa}=$ Water applied $\left(\mathrm{m}^{3} /\right.$ fed.). (Irrigation water + effective rainfall)

Note: effect rainfall $=$ rianfall $* 0.7($ Novica, 1979$)$

Consumptive use efficiency (Ecu\%):

The consumptive use efficiency (Ecu) was calculated as described by Doornbos and Pruitt (1977) as follows:

Where:

$$
\text { Ecu }=\frac{E T C}{A \mathbf{W}} \times 100
$$

$\mathrm{Ecu}=$ Consumptive use efficiency $\%$

$\mathrm{ETc}=$ Total evapotranspiration $\simeq$ consumptive use $\left(\mathrm{m}^{3} \mathrm{fed}^{-1}\right)$.
$\mathrm{AW}=$ Applied water to the field $\left(\mathrm{m}^{3} \mathrm{fed}^{-1}\right)$

Statistical analysis:

All data were statistically analyzed according to the technique of analysis of variance (ANOVA) as published by Gomez and Gomez (1984). Means of the treatment were compared by the least significant difference (LSD) at 5\% level and $1 \%$ level of significance which developed by Waller and Duncan (1979).

\section{$\underline{\text { Results and Discussion }}$}

Irrigation applied water and water productivities. Irrigation applied water

Water delivered by the Egyptian clover (Berseem) consists of two items, irrigation water (I W) and rainfall (RF) (299.2 and $285 \mathrm{~m}^{3}$ during the two growing seasons of $2016 / 17$ and $2017 / 18$ respectively). as shown in Table 4.

Table 4 illustrated also the seasonal values of applied irrigation water (AW) for Berseem crop. The highest values $2665.0 \mathrm{~m}^{3} \mathrm{fed}^{-1}(63.45 \mathrm{~cm})$ and $2520.0 \mathrm{~m}^{3} \mathrm{fed}^{-1}(60.0 \mathrm{~cm})$, were recorded for $\mathrm{C}_{2} \mathrm{I}_{1}$ in the first and second seasons, respectively. While, the lowest values were recorded under $\mathrm{C}_{1} \mathrm{I}_{5}$ in the two seasons with values $2075.0 \mathrm{~m}^{3} \mathrm{fed}^{-}$ $1(49.4 \mathrm{~cm})$ and $1890.0 \mathrm{~m}^{3} \mathrm{fed}^{-1}(45.0 \mathrm{~cm})$ in the first and second seasons, respectively. This result is in agreement with Shah Jahan Leghari et al., (2018) they illustrated that 12 irrigations in the

\begin{tabular}{|c|c|c|c|c|c|c|c|c|c|}
\hline \multirow{2}{*}{$\begin{array}{c}\text { Cultivation } \\
\text { methods }\end{array}$} & \multirow{2}{*}{$\begin{array}{c}\text { Irrigation } \\
\text { Treatments }\end{array}$} & \multicolumn{2}{|c|}{$\mathbf{A W}, \mathbf{m}^{-3}$} & \multicolumn{2}{|c|}{$\mathrm{AW}, \mathrm{cm}$} & \multicolumn{2}{|c|}{$\mathrm{CU}, \mathrm{cm}$} & \multicolumn{2}{|c|}{ Ecu, \% } \\
\hline & & $\begin{array}{c}1^{\text {st }} \\
\text { Season } \\
\end{array}$ & $\begin{array}{c}2^{\text {nd }} \\
\text { Season }\end{array}$ & $\begin{array}{c}1^{\text {st }} \\
\text { Season }\end{array}$ & $\begin{array}{c}2^{\text {nd }} \\
\text { Season }\end{array}$ & $\begin{array}{c}1^{\text {st }} \\
\text { Season }\end{array}$ & $\begin{array}{c}2^{\text {nd }} \\
\text { Season }\end{array}$ & $\begin{array}{c}1^{\text {st }} \\
\text { Season }\end{array}$ & $\begin{array}{c}2^{\text {nd }} \\
\text { Season } \\
\end{array}$ \\
\hline \multirow{4}{*}{$\mathrm{C}_{1}$} & $\mathrm{I}_{1}$ & 2342.5 & 2295.0 & 55.77 & 54.64 & 48.70 & 47.40 & 87.32 & 86.75 \\
\hline & $\mathrm{I}_{2}$ & 2315.5 & 2180.0 & 55.13 & 51.90 & 47.50 & 45.10 & 86.16 & 86.90 \\
\hline & $\mathrm{I}_{3}$ & 2290.0 & 2065.0 & 54.52 & 49.16 & 47.00 & 42.60 & 86.21 & 86.70 \\
\hline & $\mathrm{I}_{4}$ & 2195.0 & 1964.5 & 52.26 & 46.77 & 43.45 & 38.90 & 83.14 & 83.18 \\
\hline \multirow{2}{*}{\multicolumn{2}{|c|}{ Mean $\mathrm{C}_{1}$}} & 2075.0 & 1890.0 & 49.40 & 45.00 & 42.85 & 37.20 & 86.74 & 82.87 \\
\hline & & 2243.6 & 2078.9 & 53.42 & 49.49 & 45.90 & 42.23 & 85.92 & 85.53 \\
\hline \multirow{5}{*}{$\mathrm{C}_{2}$} & $\mathrm{I}_{1}$ & 2665.0 & 2520.0 & 63.45 & 60.00 & 57.47 & 54.15 & 90.57 & 90.25 \\
\hline & $\mathrm{I}_{2}$ & 2600.0 & 2408.0 & 61.90 & 57.33 & 55.45 & 50.45 & 89.57 & 88.00 \\
\hline & $\mathrm{I}_{3}$ & 2504.0 & 2330.0 & 59.62 & 55.48 & 54.00 & 48.90 & 90.56 & 88.14 \\
\hline & $\mathrm{I}_{4}$ & 2431.0 & 2270.0 & 57.88 & 54.05 & 51.05 & 47.20 & 88.20 & 87.32 \\
\hline & $\mathrm{I}_{5}$ & 2388.0 & 2240.0 & 56.85 & 53.33 & 48.50 & 44.45 & 85.31 & 83.35 \\
\hline \multicolumn{2}{|c|}{ Mean $C_{2}$} & 2517.6 & 2353.6 & 59.94 & 56.04 & 53.70 & 49.54 & 89.58 & 88.40 \\
\hline \multicolumn{2}{|c|}{ Mean C } & 2380.6 & 2216.3 & 56.68 & 52.77 & 49.80 & 45.88 & 87.86 & 87.05 \\
\hline
\end{tabular}

TABLE 4. Seasonal applied water $\left(\mathrm{m}^{3}, \mathrm{~cm} / \mathrm{Fed}\right)$ Consumptive use $(\mathrm{cm})$ and consumptive use efficiency (Ecu) in the two growing seasons.

* Growing season $1=161$ days, growing season $2=165$ days, mean $=163$ days 
seasons with 15 days interval produced significant green fodder and seed yield.

Applied irrigation water for different treatments during both seasons presented given in Table 4. Comparing with dry seeds $\left(\mathrm{C}_{1}\right)$ irrigation water applied was about $10.0-12.0 \%$ less than that in wet seeds $\left(\mathrm{C}_{2}\right)$ under the same irrigation applied regime. While, the irrigation treatment $\mathrm{I}_{5}$, applied water was less $11-17 \%$ compare with $\mathrm{I}_{1}$ under the same cultivation methods.

\section{Water consumptive use $(\mathrm{cm})$}

Crop consumptive use (CU) was computed directly on the basis of water extracted by the growing plants (from the effective root zone) during the successive irrigation intervals plus that withdrawn from the last watering till harvesting. The actual soil moisture depleted considered as a direct method for determining crop water use "crop evapotranspiration, ETc".

Berseem water consumptive use as affected by cultivation methods and irrigation regimes which were tabulated in Table 4. Data illustrated that the highest $\mathrm{CU}$ value was observed under wet cultivation method $\left(\mathrm{C}_{2}\right)$ and comprised 53.70 and $49.54 \mathrm{~cm}$, for $1^{\text {st }}$ season and $2^{\text {nd }}$ season, respectively. Dry seeds cultivation methods $\left(\mathrm{C}_{1}\right)$ exhibited $\mathrm{Cu}$ values reached mean rates 14.5$15 \%$ lowers than that recorded under wet seeds cultivation method.

The mean values of seasonal $\mathrm{CU}, \mathrm{cm}$ in the two growing seasons for different irrigation regime treatments can be descended in order as: $48.70>47.50>47.0>43.45$ and $42.85 \mathrm{~cm}$ for $\mathrm{I}_{1}, \mathrm{I}_{2}$,

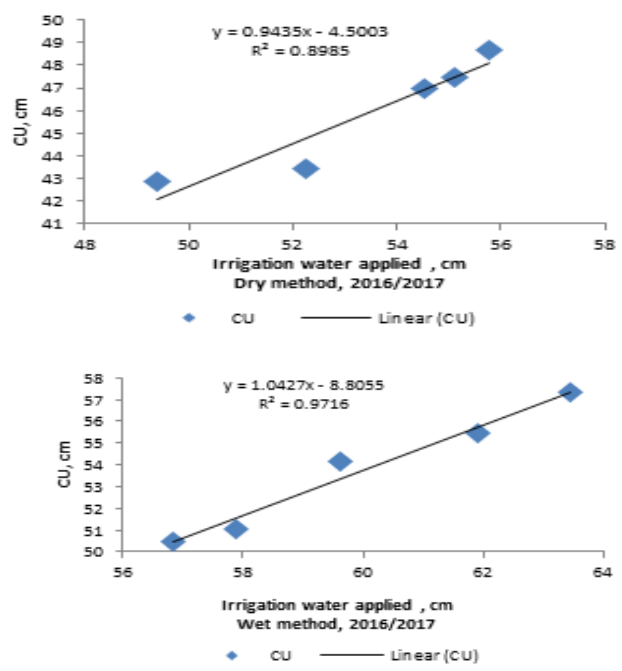

$\mathrm{I}_{3}, \mathrm{I}_{4}$ and $\mathrm{I}_{5}$ treatments respectively. While, for the second season, values are $47.40>45.10>43.05>$ 38.90 and $37.20 \mathrm{~cm}$ for treatments $I_{1}, I_{2}, I_{3}, I_{4}$ and $\mathrm{I}_{5}$ for dry cultivation methods $\left(\mathrm{C}_{1}\right)$, the same trend for wet cultivation methods $\left(C_{2}\right)$ (Table 4$)$.

The linear regression equations between applied irrigation water, $\mathrm{cm}$ overall cultivation methods on consumptive use, $\mathrm{cm}$ shown in Fig. 1 , these equations showed that, the relationship between applied irrigation water and consumed water by plants, $\mathrm{cm}$ is more reliable in the two seasons.

\section{Consumptive use efficiency (Ecu), \%}

Consumptive use efficiency (Ecu) is a parameter which indicates the capability of plants to utilize the soil moisture stored in the effective root zone. Presented values of Ecu in Table 4 showed that the highest mean values 89.58 and $88.40 \%$ were obtained under wet cultivation method $\left(\mathrm{C}_{2}\right)$ in the first and second seasons respectively. For irrigation regime treatment data revealed that the highest Ecu values were noticed under irrigation treatments $\left(\mathrm{I}_{1}\right)$ with values 90.57 and $90.25 \%$ in the first and second seasons respectively, for wet cultivation methods $\left(\mathrm{C}_{2}\right)$, the same trend for dry seeds cultivation methods. Therefore, by decreasing the applied water, higher amount of irrigation water could be beneficially used by the growing plants which resulted in decreasing water losses.

Productivity of irrigation water PIW, $\mathrm{kg} \mathrm{m}^{-3}$.

Productivity of irrigation water PIW was computed to evaluate the treatments for maximum
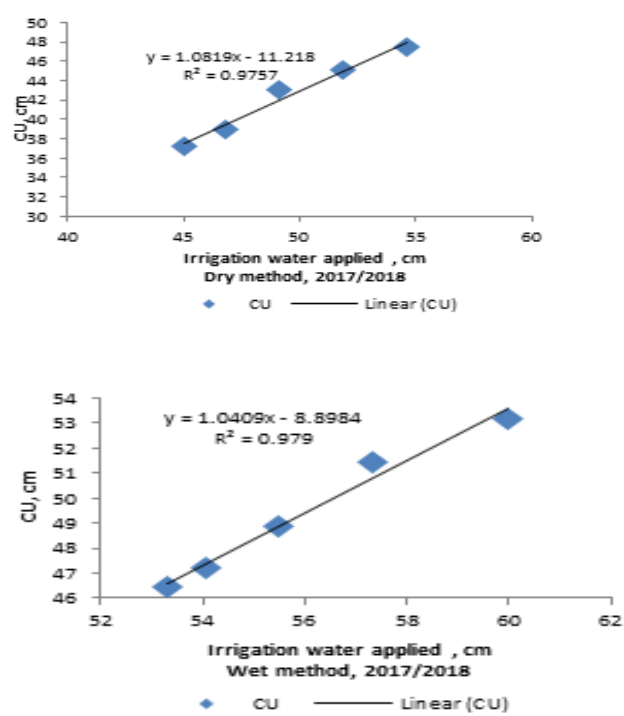

Fig. 1. Correlation between irrigation water applied, $\mathrm{cm}$ and cultivation method on consumptive use, $\mathrm{cm}$ (plant water consumption) in the two growing seasons. 
yield per unit of applied water in the field. In this case, the highest PIW for Berseem was observed under the condition of irrigation treatment $\mathrm{I}_{5}$ $\left(19.60\right.$ and $\left.21.24 \mathrm{~kg} \mathrm{~m}^{-3}\right)$ but the lowest values were noticed under $\mathrm{I}_{3}\left(17.85\right.$ and $\left.19.95 \mathrm{~kg} \mathrm{~m}^{-3}\right)$ in the first and second seasons respectively for dry cultivation methods $\left(\mathrm{C}_{1}\right)$. On the other hand for wet cultivation methods $\left(\mathrm{C}_{2}\right)$ the corresponding values were $I_{1}\left(18.16\right.$ and $\left.19.57 \mathrm{~kg} \mathrm{~m}^{-3}\right)$, and lowest values $I_{4}\left(16.75\right.$ and $18.24 \mathrm{~kg} \mathrm{~m}^{-3}$ ) (Table $5)$. So, under this study in both seasons it could be noticed that productivity of irrigation water is might be affected by; irrigation regime, cultivation methods. This result is in agreement with (Bandyopadhyay and Mallick, 2003) they found that productivity of irrigation water increased when irrigation intervals increased. Data in the same table illustrated that; the interaction among both of cultivation methods and irrigation regime have a significant effect on productivity of irrigation water.

For cultivation methods, cubic metre of irrigation water under $\mathrm{C}_{1}$ produced 18.83 and $20.60 \mathrm{~kg}$ in first and second growing seasons, respectively. Otherwise, cubic meter of irrigation water under $\mathrm{C}_{2}$ produced 17.55 and $19.77 \mathrm{~kg}$ in first and second growing seasons, respectively.

\section{Water productivity (WP, $\mathrm{kg} \mathrm{m}^{-3}$ ).}

Data in Table 5 revealed that the values of WP, were significantly affected by cultivation methods and irrigation water regime, the highest values of WP resulted from $\mathrm{I}_{2}$ compared to other treatments with other cultivation methods treatments as mean of the two growing seasons, this may be due to the higher fresh yield with low applied irrigation water compared to the other treatments, While the lowest values of WP resulted from I3 overall cultivation methods treatments.

Significant effect also for cultivation methods, Hence, cubic metre of irrigation water under $\mathrm{C}_{1}$ (dry seeds) produced 24.14 and $23.16 \mathrm{~kg}$ in first and second growing seasons, respectively, while for wet seeds produced 21.62 and $20.42 \mathrm{~kg}$ in first and second growing seasons, respectively. Table 5 showed that; irrigation regime-cultivation methods interactions significantly affect water productivity in the second season only. This result is in agreement with Kassab et al. (2012) they revealed that under dry berseem cultivation, the highest mean WP $\left(16.51 \mathrm{~kg} \mathrm{~m}^{-3}\right)$ was noticed irrigation water with $80 \%$ calculated based on Ibrahim equation. Also Abdolrahman Barzegar et

TABLE 5. Seasonal productivity of irrigation water (PIW) and irrigation water productivity (WP) for Egyptian clover as affected by cultivation methods and different irrigation treatments in the two growing seasons.

\begin{tabular}{|c|c|c|c|c|c|c|c|}
\hline \multirow{2}{*}{$\begin{array}{c}\text { Cultivation } \\
\text { methods }\end{array}$} & \multirow{2}{*}{$\begin{array}{l}\text { Irrigation } \\
\text { treatments }\end{array}$} & \multicolumn{3}{|c|}{ PIW, kg m } & \multicolumn{3}{|c|}{ WP, $\mathrm{kg} \mathrm{m}^{-3}$} \\
\hline & & $1^{\text {st }}$ Season & $2^{\text {nd }}$ Season & Mean & $1^{\text {st }}$ Season & $2^{\text {nd }}$ Season & Mean \\
\hline \multirow{3}{*}{$\mathrm{C}_{1}$} & $\mathrm{I}_{1}$ & 19.48 & 20.44 & 20.02 & 22.44 & 23.56 & 23.00 \\
\hline & $\mathrm{I}_{2}$ & 19.27 & 21.08 & 20.18 & 23.74 & 24.32 & 24.03 \\
\hline & $\mathrm{I}_{3}^{2}$ & 17.97 & 19.95 & 18.96 & 20.85 & 22.79 & 21.82 \\
\hline \multirow{6}{*}{$\mathrm{Me}$} & $\mathrm{I}_{4}$ & 17.85 & 20.27 & 19.06 & 21.46 & 24.38 & 22.92 \\
\hline & $\mathrm{I}_{5}$ & 19.60 & 21.24 & 20.36 & 22.48 & 25.60 & 24.04 \\
\hline & & 18.83 & 20.60 & 19.72 & 22.19 & 24.14 & 23.16 \\
\hline & $\mathrm{I}_{1}$ & 18.16 & 19.57 & 18.87 & 19.15 & 22.10 & 20.63 \\
\hline & $\mathrm{I}_{2}$ & 18.06 & 19.85 & 18.96 & 20.17 & 22.13 & 21.15 \\
\hline & $\mathrm{I}_{3}$ & 17.02 & 18.24 & 17.63 & 18.64 & 21.43 & 20.04 \\
\hline & $\mathrm{I}_{4}$ & 16.75 & 18.25 & 17.50 & 19.20 & 20.89 & 20.05 \\
\hline & $\mathrm{I}_{5}$ & 17.77 & 18.75 & 18.26 & 20.83 & 22.49 & 21.66 \\
\hline \multicolumn{2}{|c|}{ Mean $\mathrm{C}_{2}$} & 17.55 & 18.93 & 18.24 & 19.22 & 21.62 & 20.42 \\
\hline \multicolumn{2}{|c|}{ Mean C } & 18.19 & 19.77 & 18.97 & 20.71 & 22.88 & 21.79 \\
\hline \multicolumn{2}{|c|}{ L S D 0.05} & 0.265 & 0.545 & --- & 0.720 & 0.603 & --- \\
\hline \multirow{3}{*}{ F test } & I & $* * *$ & $* *$ & --- & $* *$ & $* *$ & --- \\
\hline & $\mathrm{C}$ & $*$ & $*$ & --- & $* *$ & $* *$ & --- \\
\hline & $\mathrm{I}^{*} \mathrm{C}$ & $* *$ & $*$ & --- & NS & $*$ & --- \\
\hline
\end{tabular}


al., 2016 illustrated Water use efficiencies are 0.32 and $0.20 \mathrm{~g} \mathrm{l}^{-1}$ for $100 \%$ and $60 \%$ field capacities, respectively.

\section{Egyptian clover yield}

Fresh yield of Egyptian clover, ton $\mathrm{fed}^{-1}$

The highest values of fresh yield were obtained under $\mathrm{I}_{1} \mathrm{C}_{2}$ with significant differences between them over both two growing seasons. Data in Table 6 cleared out that total fresh yield of berseem seemed to reduce under dry cultivation in 2016/2017 and 2017/2018 seasons and overall mean as well. The reduction in total fresh yield, due to dry cultivation, comprised mean $4 \%$ less than those recorded under wet cultivation, respectively, in 2016/2017 and 2017/2018 seasons.

Convenient irrigation (control) resulted in higher berseem fresh yield than those obtained as irrigation water quantities were applied based on other treatments and such findings were noticed in 2016/2017 and 2017/2018 seasons besides the overall mean. Data in Table 6 showed that irrigation treatments significantly affected on fresh yield. The highest mean values 47.31 and 49.34 ton fed $^{-1}$ are obtained under traditional irrigation (the highest applied water) in the first and second seasons, respectively. While, the corresponding lowest values were recorded under $\mathrm{I}_{4}$ (Hargreaves equation) with values 40.73 and 41.41 ton $\mathrm{fed}^{-1}$ in the first and second seasons, respectively for wet cultivation $\mathrm{C}_{2}$, the same trend for dry cultivation $\mathrm{C}_{1}$. Decreasing watering level from traditional method $\mathrm{I}_{1}$ by implementing Hargreaves equation $\mathrm{I}_{4}$ instated that trend it irrigation a decreasing of $\approx 6.64$ ton fed $^{-1}$ fresh yield and mean water saving of $\approx 8.17 \%$ ( $\approx 190.68 \mathrm{~m}^{3} \mathrm{fed}^{-1}$.) $)$ could be resulted for dry cultivation method, but for wet cultivation method irrigation a decreasing of $\approx 7.5$ ton $\mathrm{fed}^{-1}$ fresh yield and mean water saving of $\approx 11.12 \%$ $\left(\approx 290.22 \mathrm{~m}^{3} \mathrm{fed}^{-1}\right.$.). The results are in the same fine with by El-Bably (2002), indicated that three irrigation events between cuttings significantly increased total cuttings of Egyptian clover fresh yields, also; Kassab et al. (2012) reported that traditional or convenient irrigation resulted higher Berseem fresh yield with this obtained under 100,80 and $60 \%$ from Ibrahim eqution.

The linear regression equations between irrigation applied water, $\mathrm{cm}$ and cultivation methods on Berseem fresh yield, ton $\mathrm{fed}^{-1}$ are shown in Fig. 2. These equations showed that, the relationship between applied irrigation water quantities and fresh yield, ton $\mathrm{fed}^{-1}$ is more reliable

TABLE 6. Seasonal fresh yield (ton fed $^{-1}$ ) for Egyptian clover as affected by cultivation methods and different irrigation treatments in the two growing seasons.

\begin{tabular}{|c|c|c|c|c|c|c|c|c|c|}
\hline \multirow{3}{*}{$\begin{array}{l}\text { Cultivation } \\
\text { methods }\end{array}$} & \multirow{3}{*}{$\begin{array}{l}\text { Irrigation } \\
\text { treatments }\end{array}$} & \multicolumn{8}{|c|}{ Seasonal fresh yield, ton fed $^{-1}$} \\
\hline & & \multicolumn{4}{|c|}{$1^{\text {st }}$ Season } & \multicolumn{4}{|c|}{$2^{\text {nd }}$ Season } \\
\hline & & $\mathbf{1}^{\text {st }} \mathrm{cut}$ & $2^{\text {nd }}$ cut & $3^{\text {rd }}$ cut & Total I & $1^{\text {st }}$ cut & $2^{\text {nd }}$ cut & $3^{\text {rd }}$ cut & Total I \\
\hline \multirow{5}{*}{$\mathrm{C}_{1}$} & $\mathrm{I}_{1}$ & 17.55 & 14.98 & 13.38 & 45.91 & 16.83 & 16.07 & 14.00 & 46.90 \\
\hline & $\mathrm{I}_{2}$ & 16.88 & 14.61 & 13.13 & 44.62 & 16.93 & 16.17 & 12.86 & 45.96 \\
\hline & $\mathrm{I}_{3}$ & 16.45 & 12.44 & 12.26 & 41.15 & 15.92 & 12.36 & 12.92 & 41.20 \\
\hline & $\mathrm{I}_{4}$ & 15.75 & 11.93 & 11.49 & 39.17 & 15.08 & 12.96 & 11.80 & 39.84 \\
\hline & $\mathrm{I}_{5}$ & 15.00 & 12.98 & 12.44 & 40.42 & 14.15 & 13.87 & 12.13 & 40.15 \\
\hline \multicolumn{2}{|c|}{ Mean $\mathrm{C}_{1}$} & 16.33 & 13.39 & 12.54 & 42.26 & 15.78 & 14.29 & 12.74 & 42.81 \\
\hline \multirow{5}{*}{$\mathrm{C}_{2}$} & $\mathrm{I}_{1}$ & 18.06 & 15.25 & 14.00 & 47.31 & 17.79 & 16.85 & 14.70 & 49.34 \\
\hline & $\mathrm{I}_{2}$ & 17.64 & 15.74 & 13.58 & 46.96 & 17.57 & 16.8 & 13.44 & 47.81 \\
\hline & $\mathrm{I}_{3}$ & 17.00 & 12.74 & 12.88 & 42.62 & 16.45 & 12.74 & 13.30 & 42.49 \\
\hline & $\mathrm{I}_{4}$ & 16.44 & 12.32 & 11.97 & 40.73 & 15.37 & 13.72 & 12.32 & 41.41 \\
\hline & $\mathrm{I}_{5}$ & 15.54 & 13.95 & 12.95 & 42.44 & 14.91 & 14.28 & 12.81 & 42.00 \\
\hline \multicolumn{2}{|c|}{ Mean $\mathrm{C}_{2}$} & 16.94 & 14.00 & 13.08 & 44.02 & 16.42 & 14.88 & 13.31 & 44.61 \\
\hline \multicolumn{2}{|c|}{ Mean C } & 16.64 & 13.70 & 12.81 & 43.14 & 16.10 & 14.59 & 13.03 & 43.72 \\
\hline \multicolumn{2}{|c|}{ LSD 0.05} & 0.453 & 0.313 & 0.539 & --- & 0.423 & 0.652 & 0.442 & --- \\
\hline \multirow{3}{*}{ F test } & I & $* *$ & $* *$ & $*$ & --- & $*$ & $* *$ & $*$ & --- \\
\hline & $\mathrm{C}$ & $* *$ & $* *$ & $* *$ & --- & $* *$ & $* *$ & $* *$ & --- \\
\hline & $\mathrm{I}^{*} \mathrm{C}$ & NS & $*$ & NS & --- & NS & NS & NS & --- \\
\hline
\end{tabular}

Env. Biodiv. Soil Security Vol. 2 (2018) 
in the two seasons.

\section{Dry yield of Egyptian clover}

For dry yield of Egyptian clover, the three cuttings were considered as the total yield. Data presented in Table 7 revealed that increasing irrigation water treatment caused significant effect on weight of dry yield in the two seasons.

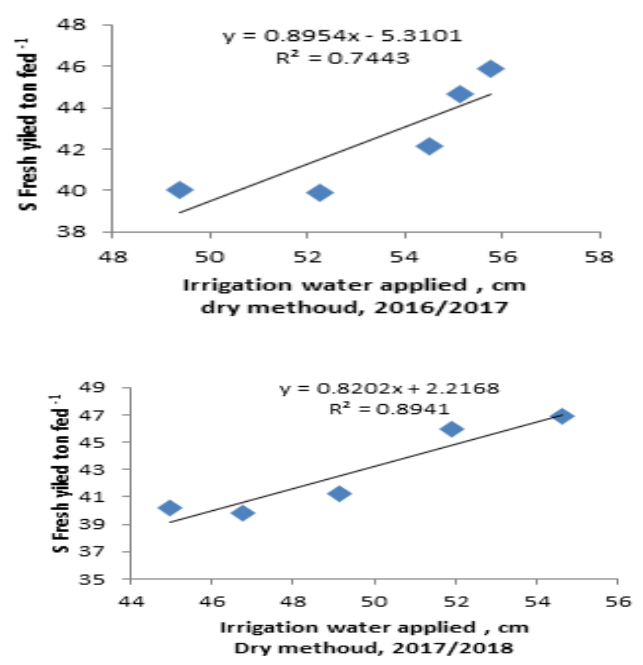

Irrigation with $\mathrm{I}_{1}$ maximized dry yield with the highest value 388.0 and $370.0 \mathrm{~kg}$. fed ${ }^{-1}$, for dry cultivation method and 419.89 and $419.23 \mathrm{~kg}$. fed ${ }^{1}$, for wet cultivation method weight in the first and second seasons respectively. On the other hand, the lowest value 354.34 and $350.16 \mathrm{~kg}$. fed ${ }^{-1}$., for dry cultivation method and 374.84 and $399.33 \mathrm{~kg}$. fed ${ }^{1}$, for wet cultivation method weight in the first and

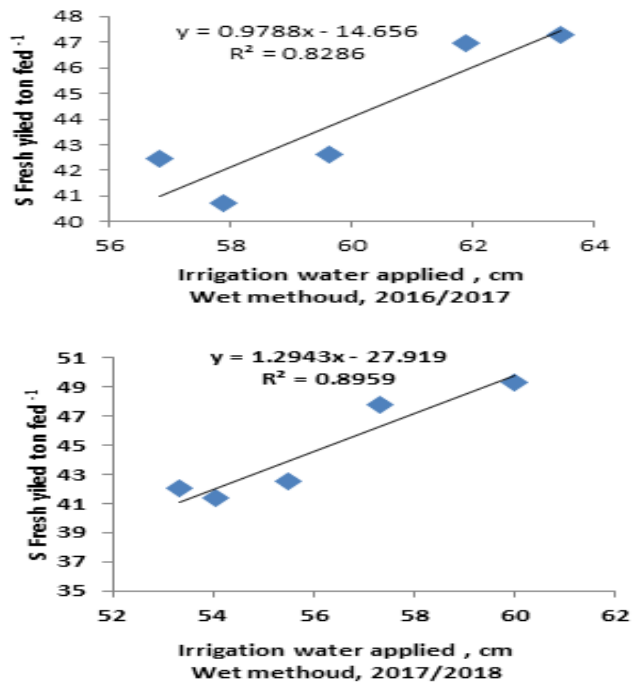

Fig. 2. Correlation between irrigation water applied, $\mathrm{cm}$ and cultivation methods on seasonal berseem clover dry yield, $\mathrm{kg} \mathrm{fed}^{-1}$ in the two growing seasons.

TABLE 7. Seasonal dry yield $\left(\mathrm{kg} \mathrm{fed}^{-1}\right)$ for Egyptian clover as affected by cultivation methods and different irrigation treatments in the two growing seasons.

\begin{tabular}{|c|c|c|c|c|c|c|c|c|c|}
\hline \multirow{3}{*}{$\begin{array}{l}\text { Cultivation } \\
\text { methods }\end{array}$} & \multirow{3}{*}{$\begin{array}{l}\text { Irrigation } \\
\text { treatments }\end{array}$} & & & & onal dry & $\mathrm{Id}, \mathrm{kg}$ fe & & & \\
\hline & & \multicolumn{4}{|c|}{$1^{\text {st }}$ Season } & \multicolumn{4}{|c|}{$2^{\text {nd }}$ Season } \\
\hline & & $1^{\text {st }}$ cut & $2^{\text {nd }}$ cut & $3^{\text {rd }}$ cut & Total I & $1^{\text {st }}$ cut & $2^{\text {nd }}$ cut & $3^{\text {rd }}$ cut & Total I \\
\hline \multirow{4}{*}{$\mathrm{C}_{1}$} & $\mathrm{I}_{1}$ & 90.63 & 131.33 & 166.16 & 388.12 & 103.00 & 122.00 & 145.00 & 370.00 \\
\hline & $\mathrm{I}_{2}$ & 103.00 & 127.33 & 139.83 & 370.16 & 101.40 & 125.66 & 131.33 & 358.39 \\
\hline & $\mathrm{I}_{3}$ & 94.52 & 132.90 & 140.00 & 367.42 & 91.40 & 125.33 & 141.66 & 358.39 \\
\hline & $\mathrm{I}_{4}$ & 94.68 & 103.00 & 156.66 & 354.34 & 84.83 & 117.33 & 148.00 & 350.16 \\
\hline \multirow{2}{*}{\multicolumn{2}{|c|}{ Mean $\mathrm{C}_{1}$}} & 97.00 & 122.00 & 144.50 & 363.50 & 86.50 & 134.50 & 136.00 & 357.00 \\
\hline & & 93.97 & 123.31 & 149.43 & 368.71 & 93.43 & 124.96 & 140.40 & 358.79 \\
\hline \multirow{5}{*}{$\mathrm{C}_{2}$} & $\mathrm{I}_{1}$ & 94.10 & 146.79 & 179.00 & 419.89 & 96.67 & 148.23 & 174.33 & 419.23 \\
\hline & $\mathrm{I}_{2}$ & 107.13 & 135.36 & 160.55 & 403.04 & 99.30 & 152.20 & 160.00 & 411.5 \\
\hline & $\mathrm{I}_{3}$ & 98.4 & 144.60 & 157.21 & 400.21 & 107.66 & 141.00 & 162.50 & 411.16 \\
\hline & $\mathrm{I}_{4}$ & 76.40 & 136.90 & 161.55 & 374.84 & 92.67 & 129.33 & 177.33 & 399.33 \\
\hline & $\mathrm{I}_{5}$ & 90.80 & 117.00 & 175.64 & 383.44 & 109.00 & 139.00 & 160.33 & 408.33 \\
\hline \multicolumn{2}{|c|}{ Mean $\mathrm{C}_{2}$} & 93.37 & 136.13 & 166.79 & 396.29 & 101.06 & 141.95 & 166.90 & 409.91 \\
\hline \multicolumn{2}{|c|}{ Mean C } & 93.67 & 129.72 & 158.11 & 382.50 & 97.25 & 133.46 & 153.65 & 384.36 \\
\hline \multicolumn{2}{|c|}{ LSD 0.05} & 6.540 & 2.522 & 4.951 & --- & 4.585 & 4.001 & 4.486 & --- \\
\hline \multirow{3}{*}{$F$ test } & I & $*$ & $*$ & $*$ & --- & $* *$ & $* *$ & $*$ & --- \\
\hline & $\mathrm{C}$ & $* *$ & $* *$ & $* *$ & --- & $* *$ & $* *$ & $* *$ & --- \\
\hline & $\mathrm{I}^{*} \mathrm{C}$ & $*$ & NS & NS & --- & $*$ & $*$ & $*$ & --- \\
\hline
\end{tabular}


second seasons respectively which yielded from the irrigation water applied of $\mathrm{I}_{4}$.

The results obtained from this study showed that when Berseem crop is given its full water requirement, 577.7 and $546.4 \mathrm{~mm}$ of water is required for dry cultivation and 634.5 and $600.0 \mathrm{~mm}$ is required for wet cultivation in first and second seasons respectively, but a figure of 494.0 and $450.0 \mathrm{~mm}$ is required for dry cultivation and 568.5 and $533.3 \mathrm{~mm}$ is required for wet cultivation when deficit irrigation resulted in saving water of $\approx 19.10 \%\left(\approx 442.8 \mathrm{~m}^{3} \mathrm{fed}^{-1}\right.$., $)$ for dry cultivation and $\approx 7.00 \%\left(\approx 181.45 \mathrm{~m}^{3} \mathrm{fed}^{-1}\right.$., $)$ for wet cultivation of the crop water requirement is applied in the two seasons with a reduction in dry yield $(\approx 4.95 \%$ and $5.64 \%)$ for dry and wet cultivation compared with the local or traditional
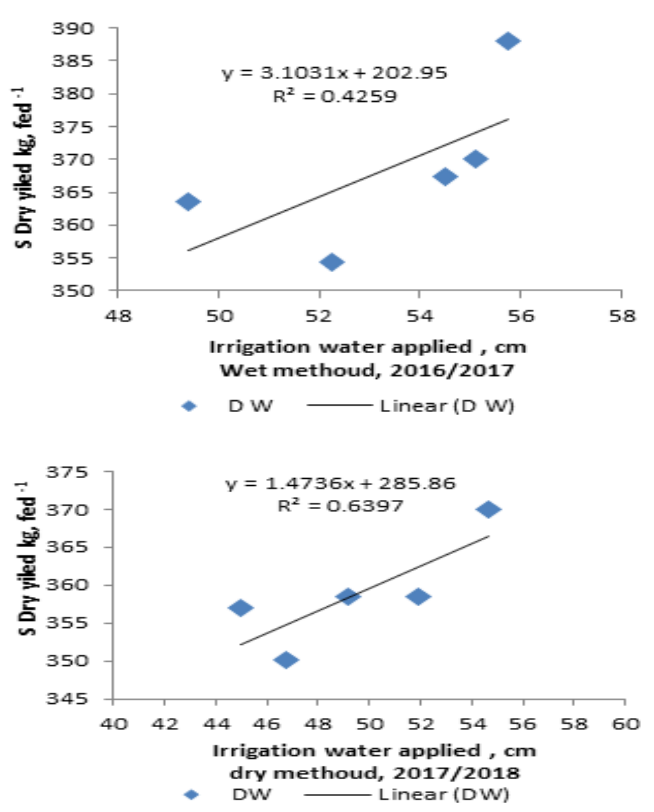

Fig. 3. Correlation between irrigation water applied, $\mathrm{cm}$ and cultivation methods on seasonal berseem clover dry yield, $\mathrm{kg} \mathrm{fed}^{-1}$.

The linear regression equations between irrigation water applied, $\mathrm{cm}$ and cultivation methods on berseem clover dry yield, $\mathrm{kg} \mathrm{fed}^{-1}$ are shown in Fig. 3, is reliable in the two seasons.

\section{Conclusion}

Although the traditional (full irrigation method, till $5 \mathrm{~cm}$ above soil surface) offers considerable advantage for fresh and dry yield to Egyptian clover crop under the arid climate conditions, $\mathrm{I}_{5}$ (till $2.5 \mathrm{~cm}$ above soil surface) saved about $\approx 14.50 \%\left(336.0 \mathrm{~m}^{3} \mathrm{fed}^{1}\right)$ for dry method and $\approx 10.75 \%$ ( $\left.280.0 \mathrm{~m}^{3} \mathrm{fed}^{1}\right)$ for wet method of IW with the highest WP values for yield to irrigation. These findings are in agreement with those of Lazaridou, Martha and Koutroubas (2004), at Drama, Macedonia, Greece, indicated that stated that water stress resulted in a reduction of the above ground dry biomass to one third of irrigated berseem clover plants, Kassab et al., (2012) stated that total dry yield of berseem clover tended to reduce under both dry and semi - dry cultivation methods in the two seasons and overall mean as well and also illustrated that reduction in total dry yield due to dry and semi - dry cultivation methods, comprised 7.63 and $2.08 \%$ and 4.56 and $2.68 \%$ lesser than those recorded under wet cultivation method, respectively, in two seasons. Also Abdolrahman Barzegar et al., 2016 illustrated that the highest $\left(0.47 \mathrm{~g} \mathrm{pot}^{-1}\right)$ and lowest $\left(0.33 \mathrm{~g} \mathrm{pot}^{-1}\right)$ total dry masses were observed at $80 \%$ and $60 \%$ field capacities.
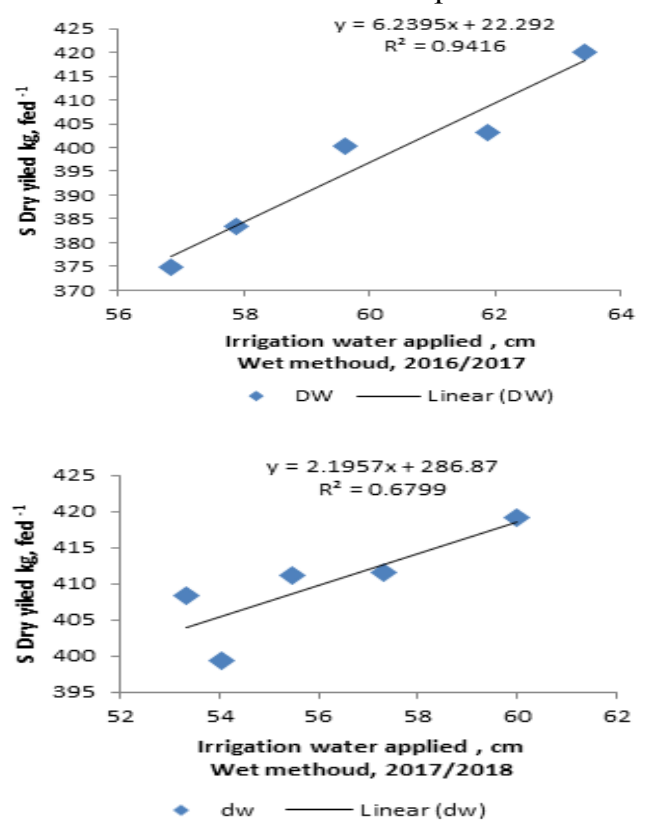

berseem clover. Investigation should focus on this issue and evaluates the efficiency of the irrigation water regime and cultivation methods for berseem production.

\section{References}

Abbas, F.A., A.A. Rayan, K.A. Mohamed and N.G. Ainer (1995). Evaluation of water management system for clover in Egypt. Proc. of The $2^{\text {Nd }}$ Conf. of On-Farm Irrigation and Agroclimatology, Egypt. P. 265-276.

Abdolrahman Barzegar, Abdolamir Yousefi and Nazanin Zargoosh (2016). Water stress and soil compaction impacts on clover growth and nutrient 
concentration. Eurasian J. of Soil Science 5(2): 139.145

Ali M.H., Hoque M.R., Hassan A.A. and Khair A. (2007). Effect of deficit irrigation on yield water productivity, and economic returns of wheat. Agric. Water Manag., 92(3): 151-161.

Bandyopadhyay, P.K. and S. Mallick (2003). Actual evapotranspiration and crop coefficients of wheat (Triticum aestivum) under varying moisture levels of humid tropical canal command area. Agric. Water Manag. 59: 33-47.

Black, C. A. (1965). Method of Soil and Water Analysis. Part 2: Madison, Wisconsin, USA.

Din SI, Ullah GD, Khan M, et al. (2014) Sowing dates and irrigation schedule influenced on yield and yield components of berseem in district Peshawar. J Nat Sci Res 4: 91-95.

Doorenbos, J. and W.O. Pruitt (1977). Guidelines for predicting crop water requirements. FAO Irrig. Drain. Pap. 24.

El-Bably, A. Z. (2002). Effect of Irrigation and Nutrition of Copper and Molybdenum on Egyptian Clover (Trifolium alexandrnium L.). Agronomy Journal, 94: 1066-1070.

Geerts, S. and D. Raes, (2009). Deficit irrigation as an on-farm strategy to maximize crop water productivity in dry areas. Agricultural Water Management, 96 (9):1275-1284.

Gomez K. A. and Gomez A. (1984). Statistical Procedures for Agricultural Research. $1^{\text {st }}$ ed. John Wiley \& Sons, New York, U.S.A.

Hansen, V.W.; Israelsen D.W. and Stringharm D.E. (1979). Irrigation Principle and Practices, $4^{\text {th }}$ ed Johns Willey \&Sons; New York, USA.

Hargreaves Gl.; Hargreaves, GH and riley, J. P. (1985). Irrigation water requirement for Senegal River Basin. J Irrigation at Drainage Engr., ASCE, 111 (3): 265-275.

Jackson, M. T. (1967). Soil Chemical Analysis, Printic Hall of India. Pivate, New York. USA. for a Changing World, 1 - 6 August 2010, Brisbane, Australia. Published on DVD.

Kassab, M.M. (2006). Dry cultivation as an effective method for berseem irrigation management. Annals of Agric. Sci., Moshtohor, 44(1).

Kassab, M.M.; M.A.M. Ibrahim and N.I. Talha (2012). Effect of cultivation method and irrigation rate on productivity and water efficiency of berseem cropgrown in North Nile Delta. Minufiya J. Agric. Res. Vol. 37 No 4(2): 1019-1033.

Lazaridou, Martha and S.D. Koutroubas (2004). Drought effect on water use efficiency of berseem clover at various growth stages. $4^{\text {th }}$ International Crop Science Congress Brisbane, Australia.

Majumdar, D.K. (2002). Irrigation Water Management: Principles and Practice. 2nd ed. Prentice Hall of India, New Delhi 110001, 487p

Novica, V(1979) Irrigation of Agriculture Crops. Fac. Agric. Press, Nvia sad, Yugoslavia.

Nyati, C.T., (1996). Effect of irrigation regime on cane and sugar yields of variety NCo376 in the southeast lowveld of Zimbabwe. Proc. South African Sugar Technologists Assn. 70. pp. 59-62.

Shah Jahan Leghari1, Aijaz Ahmed Soomro2, Ghulam Mustafa Laghari2, Khalid Hussain Talpur2, Farooque Ahmed Soomro2, Mazhar Hussain Mangil and Naveed Mahmood (2018) Effect of NPK rates and irrigation frequencies on the growth and yield performance of Trifolium alexandrium L. AIMS Agriculture and Food, 3(4): 397-405.

Singh, R., van Dam, J.C., Feddes, R.A., (2006). Water productivity analysis of irrigated crops in Sirsa district. India. Agric. Water. Manage. 82: 253-278.

Tyagi, N. K., D. K. Sharma and S. K. Luthra (2000) Evaporation crop coefficients of wheat and sorghum. Journal of Irrigation and Drainage Engineering. p 215-222.

Vazifedoust M., J.C. van Dama; R.A. Feddes and M. Feizi (2008) Increasing water productivity of irrigated crops under limited water supply at field scale. Agricultural Water Management 95: 89 102.

Waller, R.A. and Duncan D.B. (1969). Symmetric multiple comparison problem. Amer. Stat. Assoc. Jour., pp1485 - 1503.

Zemenchik, R.A., Albrecht, K.A., Shaver, R.D., (2002). Improved nutritive value of kura cloverand birdsfoot trefoil-grass mixtures compared with grass ultures. Agron. J. 94 (5), 1131-1138.

(Received 20/12/2018; accepted 12/2/2019) 